\title{
Grupo Nós Mulheres
}

A articulaçáo entre as questóes derivadas das temáticas do gênero, das demandas originárias das diferentes faixas etárias, dos diferentes grupos étnico-raciais e das diferentes classes e fraçóes de classe constitui uma perspectiva rica para a pesquisa nas ciências sociais e para a ação estratégica sobre a vida social. Nos locais periféricos aos centros dinâmicos do capitalismo se fazem sentir as consequências mais cruéis desta forma de organização social. A Região Norte do Brasil possui os piores indicadores sociais deste vasto país. O estado do Pará é um exemplo da triste designação de possuir os piores indicadores econômicos do país; além das enormes desigualdades sociais e crescimento desordenado também ostenta altos índices de violência contra quaisquer grupos locais que se organizem para defender seus direitos. No que se refere ao tráfico de pessoas, à exploração do trabalho infantil doméstico e ao trabalho escravo, o Pará possui os índices mais elevados do país.

Neste Estado a pobreza e a falta de acesso à educação formal, somadas à desigualdade de gênero, comprometem em demasia o seu desenvolvimento social. Questôes vinculadas aos direitos das mulheres, das crianças e de adolescentes, violência e mulher, juventude e violência e relaçóes raciais, e suas inter-relaçóes mostram-se de grande relevância político-econômico-cultural para a realidade local, regional, em conjunto com outras questóes de igual importância, como a discriminação aos trabalhadores e trabalhadoras, o tráfico de meninas e mulheres para fins de exploração sexual, comercial e outras.

O Grupo tem o papel de articulador estratégico e propulsor de iniciativas que reinscrevam a cor/raça e/ou etnia como componente simbólico instituinte de sujeitos sociais inter-relacionados com gênero e classe. Tais contextos remetem a padróes tradicionais rígidos de desigualdade de gênero, cor e classe e às suas inter-relaçóes, tornando-se cada vez mais imperativa a retomada deste foco de análise e interpretaçáo para o campo de estudos voltados para as Regióes Norte e Nordeste brasileiras.

Site do grupo: http://www.organizacaonosmulheres.com.br/nosmulheres.php 